\title{
Nitrogen leaching from a forest soil exposed to fire retardant with and without fire: A laboratory study
}

\author{
Athina A. PAPPA*, Nikolaos E. TzAmTzIs, Sofia E. Koufopoulou \\ National Technical University of Athens, School of Chemical Engineering, Laboratory of Inorganic and Analytical Chemistry, 9 Iroon Polytechniou \\ Str. 157 73, Athens, Greece
}

(Received 30 October 2006; revised version 5 March 2007; accepted 5 July 2007)

\begin{abstract}
The application of Long Term fire Retardants (LTRs) for forest fire prevention and/or suppression purposes can result in chemicals leaching, from soil to the drainage water, during the annual rain fall period. In leachates, large concentrations of nitrogen (N), one of the major components of LTRs, could affect the groundwater quality. N leaching due to the application of a nitrogen phosphate based LTR was studied in laboratory microcosms. The concentrations of nitrate $\left(\mathrm{NO}_{3}^{-}-\mathrm{N}\right)$ and ammonium nitrogen $\left(\mathrm{NH}_{4}^{+}-\mathrm{N}\right)$ were measured in the resulting leachates from pots with forest soil and pine seedlings (Pinus halepensis) alone and in combination with fire. Up to $30 \%$ of the total $\mathrm{N}$ in the retardant was lost to leaching, primarily as $\mathrm{NO}_{3}^{-}-\mathrm{N}$. The vegetation seems to decrease to some extent the $\mathrm{N}$ leaching. The $\mathrm{N}$ leaching from treated pots with a burnt tree is lower compared with that from treated pots with a living tree, due to the partial $\mathrm{N}$ volatilization during the fire. Although this is a laboratory study, these results may be considered as rough indications of LTR environmental implications, due to the leaching of a significant part of the retardant's $\mathrm{N}$ into groundwater.
\end{abstract}

forest soil / nitrogen leaching / fire retardant / post fire / pot technique

Résumé - Lessivage d'azote dans un sol forestier exposé à un retardant de feux avec et sans feux : une étude en laboratoire. L'application de retardants à long terme des feux (LTRs) pour la prévention des incendies en forêt et/ou leur suppression peut avoir pour résultat un lessivage chimique du sol vers les eaux de drainage, pendant la période annuelle des pluies en automne. Dans les lessivats, d'importantes concentrations en azote (N), un des composants majeur des LTRs, pourraient affecter la qualité de l'eau dans les nappes phréatiques. Le lessivage d'azote attribuable à l'application de phosphate d'azote, base des LTRs, a été étudié en conditions de laboratoire. Les concentrations de nitrate $\left(\mathrm{NO}_{3}^{-}-\mathrm{N}\right)$ et d'ammonium $\left(\mathrm{NH}_{4}^{+}-\mathrm{N}\right)$ ont été mesurées dans les lessivats issus de pots remplis de sols forestiers et plantés de semis de pins (Pinus halepensis) seuls et en combinaison avec un feu. Jusqu'à $30 \%$ de l'azote total du retardant était perdu par lessivage, essentiellement sous forme de nitrate $\mathrm{NO}_{3}^{-}$. La végétation semble décroître avec l'augmentation du lessivage. Le lessivage provenant des pots contenant des arbres brûlés est plus faible que celui des pots contenant des arbres vivants, à cause d'une volatilisation partielle d'azote pendant les feux. Bien qu'il s'agisse d'une étude en laboratoire, ces résultats peuvent être considérés comme une approximation des effets environnementaux de l'application de LTRs, du fait du lessivage d'une partie significative de l'azote du retardant dans l'eau des nappes phréatiques.

sol forestier / lessivage d'azote / retardant de feux / après feux / technique des pots

\section{INTRODUCTION}

Long-Term fire Retardants (LTRs) consist of flame inhibiting chemicals dissolved in water that decrease the rate of spread and the intensity of a forest fire. Their effectiveness is a long-term even after water has been removed by evaporation. They are used as effective means of fire suppression, applied either directly on burning fuels to extinguish fire or in advance of the fire front to create control lines. In addition, they are ideal for fire prevention, applied over forests especially in climatic areas which are prone to wildland fires, e.g. the Mediterranean region [2]. As their main active ingredients are ammonium sulphate and/or phosphate salts, like agricultural fertilizers, LTRs were considered to be inert materials. Recently, they received more attention regarding their possible environmental implications, but there is little literature that addresses this subject. Little and Calfee [12] supported the idea

\footnotetext{
*Corresponding author: athpappa@orfeas.chemeng.ntua.gr
}

of the potential harmfulness of LTRs in aquatic ecosystems. The use of these chemicals in large wildfires, a discussion of their toxicity and manipulation together with direct and indirect environmental effects of fire suppression and the suppression impacts on special emphasis management areas have been referred to by Ingalsbee [9]. The effects of LTRs on shrub steppe vegetation in Northern Nevada were reported by Larson et al. [11]. The effects of LTRs on the vegetation and soil in eastern Australian heathlands were the subject of two research reports by Bell [3] and Gould et al. [7] respectively. Reviews of the environmental impact of LTRs have been reported by Adams and Simmons [1], Kalabokidis [10] and Gimenez et al. [6]. It should be noted that there is still lack of studies in the Mediterranean region, which is an area prone to wildland fires [2].

Although $\mathrm{N}$ is considered to be a soil nutrient, leaching of $\mathrm{N}$ compounds in large concentrations could threaten drainage water quality. Among $\mathrm{N}$ compounds, $\mathrm{NH}_{3}$, which comes from 
the dissociation of LTR ammonium salts, is a toxic compound. Free $\mathrm{NH}_{3}$ is $\mathrm{pH}$ dependent and its concentration is significant only in high alkaline environments. The less toxic form of ionized ammonia, $\mathrm{NH}_{4}^{+}$, is held on cation exchange sites in the soil and does not easily leach. $\mathrm{NH}_{4}^{+}$is the form of $\mathrm{N}$ readily available for use by plants. Into the soil, $\mathrm{NH}_{4}^{+}$is oxidized to nitrite $\left(\mathrm{NO}_{2}^{-}\right)$and subsequently to nitrate $\left(\mathrm{NO}_{3}^{-}\right)$by specific micro-organisms. $\mathrm{NO}_{3}^{-}$is not absorbed on to the surface of soil particles and usually are freely leached, except in variably charged soils of the humid tropics [16]. Large $\mathrm{NO}_{3}^{-}$concentrations in drinking water when combined with sewage bacteria have been blamed for the disease called methaemoglobinaemia in babies. There is also concern that stomach cancer may be related to $\mathrm{NO}_{3}^{-}$in drinking water. Possibly, there is a link between $\mathrm{NO}_{3}^{-}$concentration and the formation of algal blooms on rivers, which downgrades water quality. It should be noted that the leaching of $\mathrm{N}$ compounds from forest soil treated with the retardant, in relation to vegetation and postfire conditions, has not been studied yet.

The purpose of this work is to study the leaching of the $\mathrm{N}$ constituent of Fire-Trol 931 (an LTR based on ammonium polyphosphates, broadly used in the Mediterranean countries) from a typical Mediterranean forest soil at the laboratory scale. More specifically, the leaching of $\mathrm{NO}_{3}^{-}-\mathrm{N}$ and $\mathrm{NH}_{4}^{+}$ $\mathrm{N}$ from pots with LTR treated and untreated forest soil and pine seedlings (Pinus halepensis) from Mount Penteli (close to Athens, Greece), was studied alone and in combination with fire. A simulated annual precipitation of $50 \mathrm{~cm}$ was applied over the pots, lasting 30-days. The leaching of total $\mathrm{P}$, due to the phosphorus content of Fire Trol 931 from the treated with the retardant pots, alone and in combination with fire, has been studied in a previous work [14].

\section{MATERIALS AND METHODS}

\subsection{Materials}

Fire-Trol 931 contains ammonium polyphosphate salts as active agents, sodium-ferrocyanide as a corrosion inhibitor, and an unspecified (trade secret) wetting agent (Biogema, Aix en Provence, France). It contains $8 \% \mathrm{~N}$ totally and is used diluted to $20 \% \mathrm{v} / \mathrm{v}$. To meet the field application rate of $1.5 \mathrm{dm}^{3} \mathrm{~m}^{-2}$ [17], $132 \mathrm{~mL}$ of diluted retardant containing $2.967 \mathrm{~g}$ of $\mathrm{N}$ was applied on the surface of each pot $\left(660 \mathrm{~cm}^{2}\right)$ giving an application rate of $450 \mathrm{~kg} \mathrm{~N} / \mathrm{ha}$. This application rate is similar to the rates reported by Norris et al. [13] and Hoppmans and Bickford [8], who used 560-1120 and $337 \mathrm{~kg} \mathrm{~N} /$ ha respectively. Forest soil and pine seedlings were obtained from Mount Penteli, a characteristic forest site suffering from forest fires. Mount Penteli is covered mainly by Pinus halepensis, the most widespread trees in the Mediterranean basin [15]. The forest soil was classified as loamy, based on analysis of its grain size [14].

\subsection{Methods}

\subsubsection{Pot technique}

Plastic flowerpots were used instead of ceramic ones to prohibit inorganic species migration into the soil content of the pots during leaching experiments. The pots had an upper diameter of $45 \mathrm{~cm}$ and a height of $38 \mathrm{~cm}$. They were filled with soil or pine seedlings replanted to them at the forest spot.

For the samples which contained only soil without seedlings, a pit of $50 \mathrm{~cm}$ depth was dug. The pots were filled with intact soil by horizons, reconstituting the soil profile, as nearly as possible. An average effective soil height of $28 \mathrm{~cm}$ was reached. These pots were coded as Soil samples (S samples).

For the samples with pine seedlings, small pine trees were removed from the forested site with as much undisturbed soil around the root as possible (an intact core occupying approx. 50\% of the total pot volume), to avoid clipping the roots. The seedlings were replanted to pots, previously filled with intact soil from the bottom horizons. The filling around the intact core was completed with soil from the successive upper horizons reaching the above mentioned height of $28 \mathrm{~cm}$. These pots were coded as Soil Tree samples (ST samples).

At the bottom of each pot there was a $5 \mathrm{~cm}$ deep-drainage layer consisting of approx. $3.0 \mathrm{~kg}$ of washed gravels. An average net weight of approx. $28 \mathrm{~kg}$ was reached after the completion of the pot filling. The free surface of each pot was covered with approx. $60 \mathrm{~g}$ of pine needles (oven dried for 6 days at $40{ }^{\circ} \mathrm{C}$ ).

The pots were put under a shelter for protection against rain, freely exposed to the environmental temperature and humidity. The soils in the pots were stabilized by careful irrigation with deionized water using a perforated small canister, at a rate of $0.5 \mathrm{dm}^{3}$ every $12 \mathrm{~h}$, for a week. The duration of each irrigation step was approx. $15 \mathrm{~min}$.

Fire troll 931 was applied to selected pots, homogenously sprayed on the trees and needle surfaces, avoiding contact with the inner walls of the pots. Next the retardant was let to dry out for two days at ambient conditions. The treated pots without a tree were coded as Soil Retardant samples (SR samples) and the pots with a tree as Soil Tree Retardant samples (STR samples).

Pine trees in selected pots with and without retardant were set on fire. The upper plastic edge of these pots was covered with a hand made insulating material (glass wool bundled up in aluminum foil) for fire protection. Before burning, hot air (using hair dryers) at a temperature of $50-70{ }^{\circ} \mathrm{C}$ was directed all over the surface of the pots and the pine trees for $10 \mathrm{~min}$. Burning was initiated and forced with the aid of small quantities of pure ethanol. During burning, temperatures were measured with thermocouples at the top of the soil surface and in the interior of the trees. These pots were coded as Soil Tree Retardant Fire samples (STRF samples) and the untreated ones as Soil Tree Fire samples (STF samples).

An annual rainfall precipitation of $50 \mathrm{~cm}$ (typical in Greece) was simulated in a 30-day time period. Taking into account the upper diameter of the pot, this corresponded to irrigation of $0.5 \mathrm{dm}^{3}$ every $12 \mathrm{~h}$ following the same procedure as in soil stabilization process. Ten leachates were obtained every 3 days during this time period for each sample.

Four-experimental cycles were carried out in the duration of 4years starting in January 2003 and being repeated every January until January 2006. The age of the pine seedlings, which had similar size, varied from 2 to 4 -years. The seedlings were removed from the same forest site following the same procedure. We have treated all samples of the same category as replicas, irrespective of the cycle which they had come from. The choice of carrying the experiments in four experimental cycles, instead of examining more samples in the same experimental cycle, was due to the difficulties in handling and analyzing a great number of samples in limited time. At the end of all four experimental cycles we had to examine four replicas for each of the 
three categories of untreated pots (S, ST and STF) which have been characterized as control pots and seven replicas for each of the three categories of treated pots (SR, STR and STRF).

\subsubsection{Analytical methods}

The concentrations of $\mathrm{N}$ (as $\mathrm{NH}_{4}^{+}-\mathrm{N}$ and $\mathrm{NO}_{3}^{-}-\mathrm{N}$ ) in leachates were measured by a portable spectrophotometer (HACH DR/2010). $\mathrm{NO}_{3}^{-}$$\mathrm{N}$ was determined by the cadmium reduction method ( $\mathrm{HACH}, 8039)$ and $\mathrm{NH}_{4}^{+}-\mathrm{N}$ by Nessler method $(\mathrm{HACH}, 8038)$. It should be noted that the Nessler method determines ionized $\mathrm{NH}_{4}^{+}$and non-ionized, free $\mathrm{NH}_{3}$, as a total. As the $\mathrm{pH}$ of the leachates was below 8 in all cases, $\mathrm{NH}_{4}^{+}$rather than free $\mathrm{NH}_{3}$ is expected to be present in the leachates from all the examined pots. To control the accuracy of the $\mathrm{HACH}$ methods used, they were compared with ASTM methods, D3867-99 and D1426-98 for $\mathrm{NO}_{3}^{-}-\mathrm{N}$ and $\mathrm{NH}_{4}^{+}-\mathrm{N}$ respectively. Six real samples (leachates) were measured by both the ASTM and the HACH methods, with good agreement of the results. This procedure was repeated at the beginning of each experimental cycle.

\section{RESULTS AND DISCUSSION}

Elution curves for the leaching of $\mathrm{NH}_{4}^{+}-\mathrm{N}$ and $\mathrm{NO}_{3}^{-}-\mathrm{N}$ from retardant-treated pots and control pots are presented in Figures 1 and 2 respectively. The concentrations of $\mathrm{N}$ compounds in each collected leachate volume were plotted during a simulated annual precipitation of $50 \mathrm{~cm}$ in 30-days. Each elution curve is the average of seven and four replication experiments for treated and control pots respectively. The leaching profile of $\mathrm{NH}_{4}^{+}-\mathrm{N}$ and $\mathrm{NO}_{3}^{-}-\mathrm{N}$ in case of treated pots presented remarkable differences among replication experiments, as indicated by the size of the standard error bars in the elution curves. This was something to be expected, taking into account that an attempt was made to approach a field situation, where there is high heterogeneity in the soil and plant conditions.

The concentrations of $\mathrm{NH}_{4}^{+}-\mathrm{N}$ in leachates from treated pots were found to be higher in comparison with their controls (Figs. 1a-1c). More specifically, the concentrations of $\mathrm{NH}_{4}^{+}-\mathrm{N}$ in leachates from treated pots without a pine tree (SR samples) were found to be the highest, although they were at low levels, that is at about $3-5 \mathrm{mg} / \mathrm{L}$ (Fig. 1a). It should be noted, that the concentrations of $\mathrm{NH}_{4}^{+}-\mathrm{N}$ in leachates from control pots were below $0.5 \mathrm{mg} / \mathrm{L}$ in all cases. The increased concentrations of $\mathrm{NH}_{4}^{+}-\mathrm{N}$ which were observed in some first leachates from both treated SR and STR samples might be due to the fact that the nitrification process had not started yet, and the $\mathrm{NH}_{4}^{+}-\mathrm{N}$ application due to the retardant had exceeded the soil capacity in $\mathrm{NH}_{4}^{+}-\mathrm{N}$. The mean concentrations of $\mathrm{NH}_{4}^{+}-\mathrm{N}$ in leachates from pots with trees treated with the retardant and then subjected to fire (STRF samples, Fig. 1c) were below $1.5 \mathrm{mg} / \mathrm{L}$, at similar levels to those from STR pots (Fig. 1b). The decreased leaching of $\mathrm{NH}_{4}^{+}$-N from STR samples in comparison with that from SR samples may reflect both increased consumption of $\mathrm{NH}_{4}^{+}-$ $\mathrm{N}$ by living trees for nutrition purposes or an enhanced uptake of $\mathrm{N}$ by microbial communities that are promoted in soils with trees. As far as the case of the burnt tree is concerned (STRF samples), during the fire a significant part of initially applied $\mathrm{NH}_{4}^{+}-\mathrm{N}$ is volatilized [4].
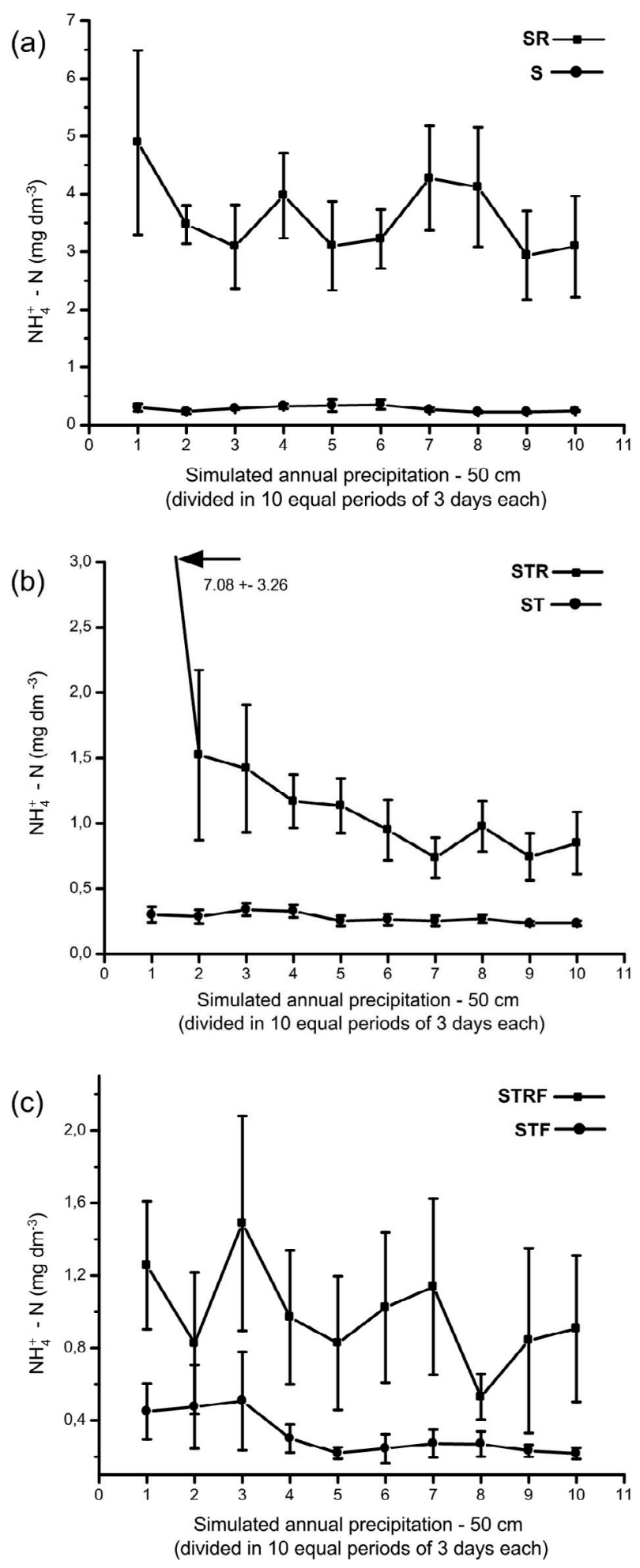

Figure 1. Concentration of $\mathrm{NH}_{4}^{+}-\mathrm{N}$ in leachates from treated with the retardant pots and their controls, without a tree: SR and S (a), with a tree: STR and ST (b) and with a tree which was subjected to fire STRF and STF samples (c), during a simulated annual precipitation $50 \mathrm{~cm}$. The mean and \pm S.E. of the measurements resulting from replicate experiments (seven for treated samples and four for their controls) are shown at each point of the elution curve. 
(a)

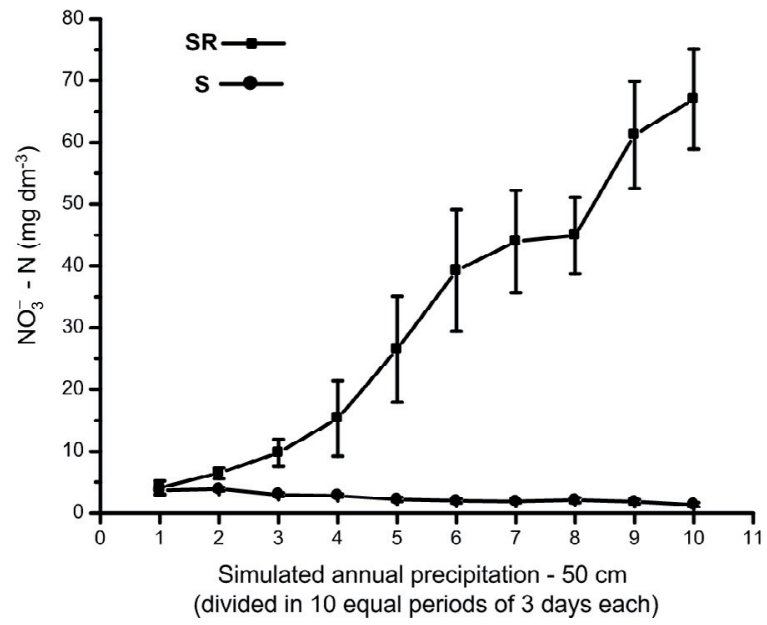

(b)

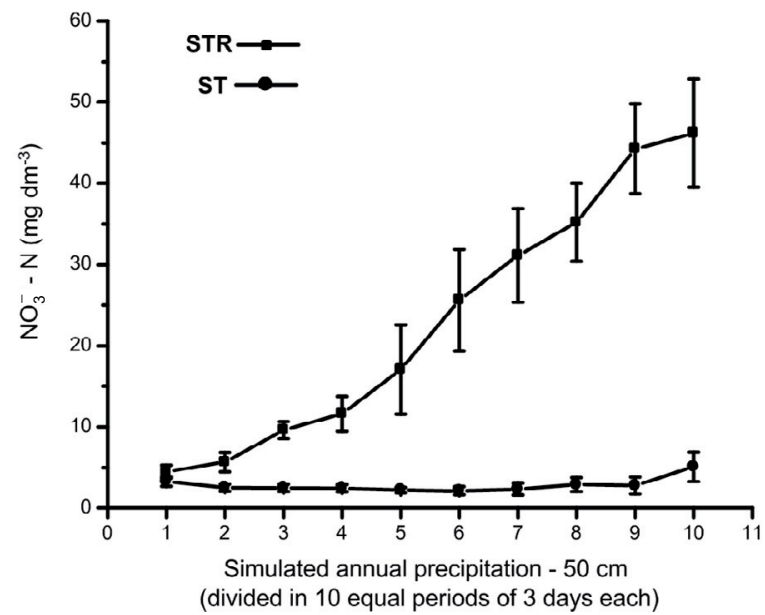

(c)

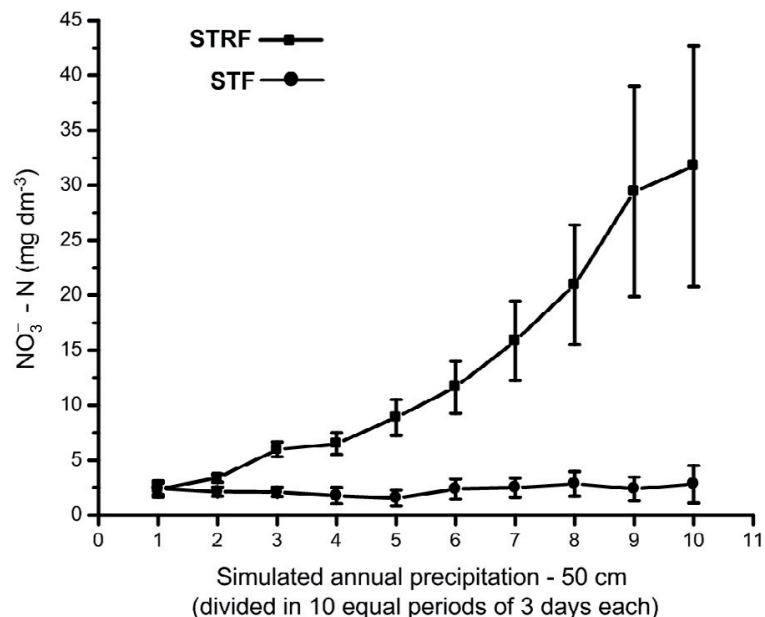

Figure 2. Concentration of $\mathrm{NO}_{3}^{-}-\mathrm{N}$ in leachates from treated with the retardant pots and their controls, without a tree: SR and $\mathrm{S}$ (a), with a tree: STR and ST (b) and with a tree which was subjected to fire STRF and STF samples (c), during a simulated annual precipitation $50 \mathrm{~cm}$. The mean and \pm S.E. of the measurements resulting from replicate experiments (seven for treated samples and four for their controls) are shown at each point of the elution curve.
Table I. Cumulative leaching of total inorganic N (mg) from treated with the retardant pots (SR, STR, STRF) and their controls (S, ST, $\mathrm{STF})^{\mathrm{a}}$ at the end of the simulated rainfall period.

\begin{tabular}{lccccc}
\hline S & ST & STF & SR & STR & STRF \\
\hline 68 & 77 & 66 & 887 & 619 & 367 \\
$8.8 \%$ & $23.3 \%$ & $62 \%$ & $33 \%$ & $27.4 \%$ & $62 \%$ \\
$60-75$ & $59-102$ & $26-115$ & $538-1347$ & $461-966$ & $66-717$ \\
4 & 4 & 4 & 7 & 7 & 7 \\
\hline
\end{tabular}

a Values are mean, coefficient of variance and range, followed by number of replications.

The average concentrations of $\mathrm{NO}_{3}^{-}-\mathrm{N}$ in leachates from all the control pots (S, ST, STF samples) were below $5 \mathrm{ppm}$. It should be noted that the concentration limit for drinkable water according to the World Health Organization is $11.3 \mathrm{ppm}$ $\mathrm{NO}_{3}^{-}-\mathrm{N}$ [16]. Significant increases in concentrations of $\mathrm{NO}_{3}^{-}$$\mathrm{N}$, in comparison with those from control pots, were observed in the leachates from all treated pots after a lag period of two weeks (Figs. 2a-2c). This is in agreement with the results published in the literature [13]. The concentrations of $\mathrm{NO}_{3}^{-}-\mathrm{N}$ in the leachates from the treated pots were still increasing at the end of the 30-day leaching cycle and reached 70, 45 and 32 $\mathrm{mg} / \mathrm{L}$ for SR, STR and STRF samples respectively.

The average cumulative leaching (in $\mathrm{mg}$ ) of total inorganic $\mathrm{N}$, after the simulated annual precipitation, from all the replication experiments is shown in Table I. In addition, the range of measurements and the coefficient of variance for the different sample categories are also depicted. In the case of STF and STRF samples were some extreme values that drastically affected the coefficient of variance due to the fire variability among replication experiments.

Non-parametric tests were applied to the comparison of the cumulative leaching of total inorganic $\mathrm{N}$ from different pots, because the assumptions of normality and equality of variances could not be satisfied. The results are summarized in Table II. From the statistical treatment it is depicted that the $\mathrm{N}$ leaching from the treated samples is significantly different among the sample categories and increased according to the following order: STRF, STR, SR.

The lower cumulative leaching of total inorganic $\mathrm{N}$ from pots with a living tree (STR samples), compared with that from treated pots without a tree (SR samples), could be attributed to the fact that a significant amount of $\mathrm{N}$ provided by the retardant was used for nutritional purposes and plant growth. However, the fertilizing impact of the retardant could be attributed also to the increased uptaking of P retardant content from the living tree, as it has been reported elsewhere [14]. This fertilizing effect (due to $\mathrm{P}$ and/or $\mathrm{N}$ constituent of the retardant) is clearly depicted in Figure 3, where the Relative Grow Rates (RGR) of the treated and control trees are plotted versus their initial heights [5]. The treated samples, at least until the end of the second year after the retardant application, have greater RGR than the control ones. It should be noted that the data concerning the tree growth were derived at the end of each year after seedlings had been replanted. 
Table II. Comparison of $\mathrm{N}$ leaching from different pots.

\begin{tabular}{|c|c|c|c|c|c|}
\hline Applied test & Compared pots & $\begin{array}{l}\text { Calculated } \\
\text { statistics }\end{array}$ & $\begin{array}{l}\text { Critical } \\
\text { value }\end{array}$ & $\begin{array}{l}\text { Significant differences } \\
(P=0.05)\end{array}$ & Results \\
\hline \multirow[t]{2}{*}{ Kruska-Wallis $\mathrm{H}$} & $\begin{array}{l}\text { Control pots (as one } \\
\text { group), SR, STR, STRF }\end{array}$ & 15.81 & 7.82 & YES & $\begin{array}{l}\text { The leaching of } \mathrm{N} \text { from treated pots is significantly } \\
\text { different from that from control pots }\end{array}$ \\
\hline & SR, STR, STRF & 9.66 & 5.99 & YES & $\begin{array}{l}\text { There are significant differences among the leach- } \\
\text { ing of } \mathrm{N} \text { from treated pots }\end{array}$ \\
\hline $\begin{array}{l}\text { Mann-Whitney } \\
\text { U-test }\end{array}$ & STR/SR & 8 & 11 & YES & $\begin{array}{l}\text { The leaching of } \mathrm{N} \text { from STR pots is significantly } \\
\text { less than that from SR pots }\end{array}$ \\
\hline $\begin{array}{l}\text { Mann-Whitney } \\
\text { U-test }\end{array}$ & STRF/STR & 10 & 11 & YES & $\begin{array}{l}\text { The leaching of N from STRF pots is significantly } \\
\text { less than that from STR pots }\end{array}$ \\
\hline
\end{tabular}

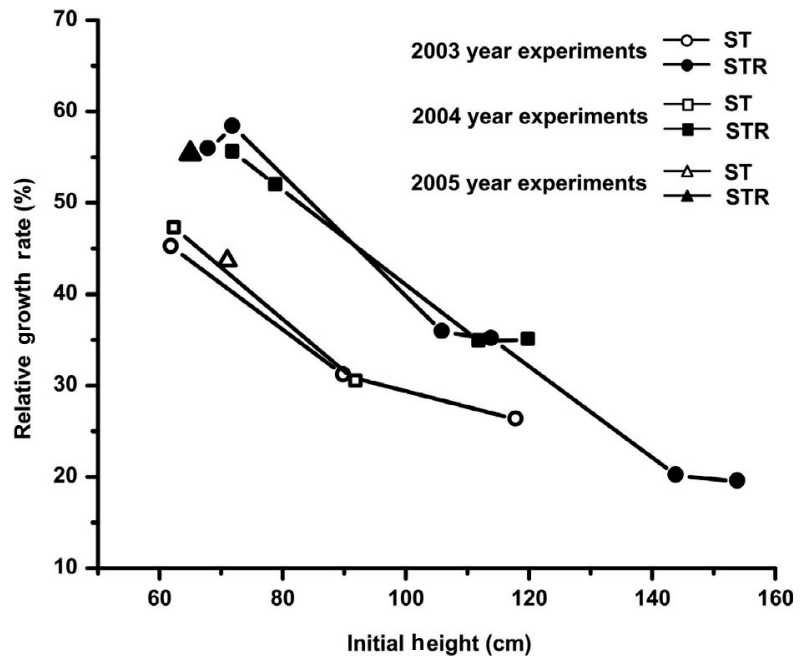

Figure 3. Relative growth rate $(\%)$ as a function of initial height $(\mathrm{cm})$ for ST and STR samples.

The pots with treated trees after having been subjected to fire (STRF samples), presented the lowest N leaching, because in fire conditions appreciable amounts of the retardant's $\mathrm{N}$ is volatilized as $\mathrm{NH}_{3}$. In our experiments, the reached temperatures of $250-300{ }^{\circ} \mathrm{C}$ in spite of their low intensity, were probably capable of volatilizing a substantial quantity of $\mathrm{N}$.

The average cumulative total inorganic $\mathrm{N}$ leaching from the treated samples was found to be 30,21 and $12 \%$ of the initially applied $\mathrm{N}$ for SR, STR and STRF respectively, using a retardant application rate of $450 \mathrm{~kg} \mathrm{~N} / \mathrm{ha}$. The above percentages are consistent with results reported in the literature. Specifically, Norris et al. [13] reported that the leached $\mathrm{NO}_{3}^{-}-\mathrm{N}$ ranges from 5.9 to $25 \%$ when using a retardant application rate of $560-1120 \mathrm{~kg} \mathrm{~N} /$ ha on constructed soil columns. It should be pointed out that the average cumulative leaching of $\mathrm{NH}_{4}^{+}-\mathrm{N}$, from all the treated samples, was lower than $3 \%$ of the initially applied $\mathrm{N}$. The leaching rates of total inorganic $\mathrm{N}$ from treated pots ranged from 56 up to $134 \mathrm{~kg} \mathrm{~N} / \mathrm{ha}$, over the entire 30 -day leaching period. The leaching rates from the control pots for the same period were $10-12 \mathrm{~kg} \mathrm{~N} / \mathrm{ha}$.

It should be noted that the leaching rate of total inorganic $\mathrm{N}$ at the end of the simulated rainfall period following the retardant application was much more than that of the $\mathrm{P}$ measured in a previous work under the same conditions [14]. So the leaching rate of up to $25 \mathrm{~kg} \mathrm{P} /$ ha resulted from the retardant application rate of $892 \mathrm{~kg} \mathrm{P} / \mathrm{ha}$, representing a small percentage $(2.4 \%)$ of the initially applied $\mathrm{P}$. The highest $\mathrm{P}$ leaching was presented from pots without a tree, therefore the presence of living trees has a positive effect on the leaching of both elements.

\section{CONCLUSIONS}

Fire-Trol 931 application resulted in the leaching of N, primarily as $\mathrm{NO}_{3}^{-}-\mathrm{N}$, to groundwater, from a typical Mediterranean forest soil in pots, following the application of a 30-day simulated annual precipitation. $\mathrm{N}$ added to the soil (as $\mathrm{NH}_{4}^{+}$$\mathrm{N})$, due to the retardant application, was found to be more than the growing vegetation could take up and the soil itself could retain. Conversion of large amounts of the applied $\mathrm{N}$ into nitrate resulted in mobile N, which leached out of pots. The vegetation seems to decrease to some extent the $\mathrm{N}$ leaching. The $\mathrm{N}$ leaching from treated pots with a burnt tree is lower compared with that from treated pots with a living tree, most likely due to the partial $\mathrm{N}$ volatilization during the fire. The retardant seems to have a positive action on tree growth, at least until the second year of its application. However, the amount of $\mathrm{N}$ leaching under the experimental conditions used was a significant percentage (up to $30 \%$ ) of the initially applied $\mathrm{N}$ quantities in all the examined cases. Although this is a laboratory study and consequently, the extrapolation of results to field conditions must be made with caution, these results could indicate negative retardant environmental implications, by entering $\mathrm{N}$ into the aquatic environment. Nevertheless, the benefits of fire retardants in fighting wildland fires must be also considered.

Acknowledgements: This study was supported by the European Community through the ERAS (EVG1-2002-0019) project. We thank Assoc. Prof. M. Statheropoulos for helpful discussions during the preparation of the experiments and the Forest Inspection Office staff of Pentelis mountain for the forest material supplies.

\section{REFERENCES}

[1] Adams R., Simmons D., Ecological effects of fire fighting foams and retardants, Proceedings of Australian Bushfire Conference, Albury, NSW, Australia, School of Environmental \& Information 
Sciences, Charles Sturt University: Albury, NSW, 1999 Available at http://www.life.csu.edu.au/bushfire99/papers.

[2] Angeler D.G., Rodriguez M., Martin S., Moreno J.M., Assessment of application-rate dependent effects of a long-term fire retardant chemical (Fire-Trol 934) on Typha domingensis germination, Environ. Int. 30 (2004) 375-381.

[3] Bell T., Effects of fire retardants on vegetation in eastern Australian heathlands: a preliminary investigation, Research Report No. 68, Fire Management, Department of Sustainability and Environment, Victoria, 2003. Available at http://www.nre.vic.gov.au/CA256F310024B628/0/A63F217A03A BB536CA257223003A35EC/\$File/Research+Report+68.pdf.

[4] Crouch R.L., Timmenga H.J., Barber T.R., Fuchsman P.C., Post-fire surface water quality: Comparison of fire retardant versus wildfirerelated effects, Chemosphere 62 (2006) 874-889.

[5] Cummings W., Jones E., Reed D., Drummer T., Frontier function analysis to estimate the maximum relative growth rate of red pine (Pinus resinosa, Ait.) in Northern Michigan, Proceedings of a IUFRO 4.11 conference held at the University of Greenwich, June 2001.

[6] Gimenez A., Pastor E., Zarate L., Planas E., Arnaldos J., Longterm forest fire retardants: a review of quality, effectiveness, applications and environmental considerations, Int. J. Wildl. Fire 13 (2004) 1-15.

[7] Gould J.S., Khanna P.K., Hutchings P.T., Assesment of the effectiveness and environmental risk of Retardants to assist in wildfire control in Victoria, Research Report No. 50, CSIRO Forestry and Forest Products, Department of Natural Resources and Environment, Victoria, 2000. Available at http://www.nre.vic.gov.au/CA256F310024B628/0/0C2E1F91D1EE 1333CA257223003C639B/\$File/Research+Report+50.pdf.

[8] Hopmans P., Bickford R., Effects of fire retardant on soils of heathland in Victoria, Fire management Department of Sustainability and Environment, Victoria, Research Report No. 70, 2003. Available at http:// www.dse.vic.gov.au/fires.
[9] Ingalsbee T., Collateral damage: the environmental effects of firefighting. Western fire ecology center-biscuit fire suppression impacts, 2004. Available at http://www.fireecology.org/research/biscuit_suppression.html.

[10] Kalabokidis K., Effects of wildfire suppression chemicals on people and the environment - a review, Global Nest, Int. J. 2 (2000) 129137.

[11] Larson D.L., Newton W.E., Anderson P.J., Stein S.J., Effect of fire retardant chemical and fire suppressant foam on shrub steppe vegetation in Northern Nevada, Int. J. Wildl. Fire 9 (1999) 115-127.

[12] Little E.E., Calfee R.D., Environmental Implications of fire retardant chemicals, Report to US Forest Service, 2002. Available at http://www.cerc.usgs.gov/pubs/center/pdfdocs/ECO-03.pdf.

[13] Norris L.A., Hawkes C.L., Webb W.L., Moore D.G., Bollen W.B. and Holcombe E., A report of research on the behaviour and impact of chemical fire retardants in forest streams, Forestry Sciences Laboratory, PNW Forest and Range Experiment Station, Corvallis, Oregon, USA, 1978.

[14] Pappa A., Tzamtzis N., Koufopoulou S., Effect of fire retardant application on phosphorus leaching from Mediterranean forest soil: short-term laboratory-scale study, Int. J. Wildl. Fire 15 (2006) 287292.

[15] Pausas J.G., Ribeiro E., Vallejo R., Post-fire regeneration variability of Pinus halepensis in the eastern Iberian Peninsula, For. Ecol. Manage. 203 (2004) 251-259.

[16] Rowell D.L., Soil Science: Methods and applications, Pearson/Prentice Hall, 1994.

[17] Xanthopoulos G., Noussia P., Small-scale evaluation of a retardantreinforced firebreak required to stop a forest fire, Mediterranean Agronomic Institute of Chania, Crete, Greece, ACRE project, Research Report, 2000. 